\title{
Anti-SARS-CoV-2 virus antibody levels in convalescent plasma of six donors who have recovered from COVID-19
}

\author{
Libo Zhang ${ }^{1,}$, Rongrong Pang ${ }^{1,}{ }^{*}$, Xiang Xue ${ }^{2}$, Jingjing Bao ${ }^{1}$, Sheng $\mathrm{Ye}^{3}$, Yudong Dai ${ }^{4}$, Yishan \\ Zheng ${ }^{5}$, Qiang $\mathrm{Fu}^{4}$, Zhiliang $\mathrm{Hu}^{6,7}$, Yongxiang $\mathrm{Yi}^{6}$ \\ ${ }^{1}$ Department of Laboratory Medicine, Nanjing Red Cross Blood Center, Nanjing 210003, Jiangsu, China \\ ${ }^{2}$ Department of Biochemistry and Molecular Biology, University of New Mexico, Albuquerque, NM 87131, USA \\ ${ }^{3}$ Department of Apheresis, Nanjing Red Cross Blood Center, Nanjing 210003, Jiangsu, China \\ ${ }^{4}$ Department of Blood Management, Administrative Office, Nanjing Red Cross Blood Center, Nanjing 210003, \\ Jiangsu, China \\ ${ }^{5}$ Department of Critical Medicine, The Second Hospital of Nanjing, Nanjing University of Chinese Medicine, \\ Nanjing 210003, Jiangsu, China \\ ${ }^{6}$ Nanjing Infectious Disease Center, The Second Hospital of Nanjing, Nanjing University of Chinese Medicine, \\ Nanjing 210003, Jiangsu, China \\ ${ }^{7}$ School of Public Health, Nanjing Medical University, Nanjing 211166, Jiangsu, China \\ *Co-first authors
}

Correspondence to: Qiang Fu, Zhiliang Hu; email: 497271360@qq.com, huzhiliangseu@163.com

Keywords: coronavirus disease 2019 (COVID-19), convalescent plasma, SARS-CoV-2 virus, anti-SARS-CoV-2 antibodies, plasma donation

Received: March 27, 2020

Accepted: April 14, 2020

Published: April 22, 2020

Copyright: Zhang et al. This is an open-access article distributed under the terms of the Creative Commons Attribution License (CC BY 3.0), which permits unrestricted use, distribution, and reproduction in any medium, provided the original author and source are credited.

\section{ABSTRACT}

Background: Anti-SARS-CoV-2 virus antibody levels in convalescent plasma (CP), which may be useful in severe Anti-SARS-CoV-2 virus infections, have been rarely reported.

Results: A total of eight donors were considered for enrollment; two of them were excluded because of ineligible routine check. Of the six remaining participants, five samples were tested weakly positive by the IgM ELISA. Meanwhile, high titers of IgG were observed in five samples. The patient treated with CP did not require mechanical ventilation 11 days after plasma transfusion, and was then transferred to a general ward.

Conclusions: Our serological findings in convalescent plasma from recovered patients may help facilitate understanding of the SARS-CoV-2 infection and establish CP donor screening protocol in COVID-19 outbreak.

Methods: Anti-SARS-CoV-2 antibodies including IgM and IgG were measured by two enzyme-linked immunosorbent assays (ELISA) in convalescent plasma from six donors who have recovered from coronavirus disease 2019 (COVID-19) in Nanjing, China. CP was also utilized for the treatment of one severe COVID-19 patient.

\section{INTRODUCTION}

By late 2019 the outbreak of coronavirus disease 2019 (COVID-19) was unchecked in China [1, 2]. Apart from supportive care, specific drugs for this disease are still being researched $[3,4]$. The absence of efficacy-proven antiviral treatment has led to attempts to treat severe
SARS-CoV-2 infection with convalescent plasma containing SARS-CoV-2 specific antibodies from recovery patients-a precedent established with pathogen-specific immunoglobulin therapy for Ebola virus disease, influenza, severe acute respiratory syndrome, and severe fever and thrombocytopenia syndrome [5-8]. 
Previous reports on other viral infections have suggested that convalescent plasma with higher antibody levels may have great effect on virus load $[9,10]$, and our study was designed to test anti-SARSCoV-2 virus antibody levels to select those with high titers, desiring a meaningful serologic response after $\mathrm{CP}$ infusion.

In accordance with $\mathrm{CP}$ infusion therapeutics guidelines approved by the National Health Commission of People's Republic of China, we used ELISA to screen for anti-SARS-CoV-2 IgM and IgG. In this report, we present our preliminary findings of anti-SARS-CoV-2 antibody levels in convalescent plasma obtained from six donors and clinical effects of one case treated with $\mathrm{CP}$ in Nanjing, China.

\section{RESULTS}

\section{Characteristics of the six CP donors}

We recruited a total of six donors including four males and two females, aged from 30 to 50 years old, with laboratory confirmed SARS-CoV-2 infection during the COVID-19 outbreak and the subsequent recovery certificated by two consecutively negative SARS-CoV2 PCR assays and resolution of clinical symptoms. All the donors had fever and cough during the course of COVID-19. None of the donors were currently smoking. Donor D had a history of brain surgery due to a benign tumor. The other five donors did not have any underlying comorbidities. The baseline blood examinations of the donors, when they were admitted to the hospital due to COVID-19, were summarized in Table 1. At the time of admission, two donors had lymphocytopenia (lymphocyte counts $<0.8 \times 10^{9} / \mathrm{L}$ ), one donor had increased alanine aminotransferase level (144 IU/L), one donor had elevated creatine kinase level (490 $\mathrm{U} / \mathrm{L}$ ), three donors had abnormal lactate dehydrogenase (ranged from 261 to $286 \mathrm{IU} / \mathrm{L}$ ) and four donors had a Creactive protein level of more than $10 \mathrm{mg} / \mathrm{L}$ (Table 1 ). Chest CT scans demonstrated bilateral pneumonia in all six donors.

During hospitalization, all donors were routinely given antiviral therapy with interferon- $\alpha(500 \mathrm{WU}$, twice a day, aerosol inhalation) and lopinavir/ritonavir (400/100mg, twice a day). Donor B, C, D, and E also received intravenous immunoglobulin. A 3-day course of corticosteroids (methylprednisolone $40 \mathrm{mg}$ per day) was administered to donor B, D and F. None of donor needed mechanical ventilation or required to be transferred to the intensive care unit. The time from onset of symptoms to clearance of virus, defined as two consecutive negative nucleic acid tests from throat swab samples, were varied from 8 to 18 days. The donors were discharged after virus clearance and substantially improvement of their pneumonia.

Plasma samples were collected at times ranging from 29 to 46 days after symptom onset, and 13 to 27 days after their discharge, respectively (Table 2). At the time of blood donation, the donors were free of any symptom. The complete blood count, liver and renal function, lactate dehydrogenase, and C-reactive protein were within the normal range. The lymphocyte subsets counts were summarized in Table 3. All ABO types were involved in the study except $\mathrm{AB}$ type. Additionally, as part of the routine check, the donated plasma was confirmed free of hepatitis $\mathrm{B}$ and $\mathrm{C}$ virus, human immunodeficiency virus (HIV) and residual SARSCoV-2 by RT-PCR and serologic negative for hepatitis $B$ and $C$ virus, HIV, and syphilis.

\section{Serological findings of anti-SARS-CoV-2 antibodies detected by ELISA}

The anti-SARS-CoV-2 IgM antibody was weakly reactive (OD ratio from 1.22 to 2.01) for all donors except donor $\mathrm{F}$, with a slightly higher OD ratio of 5.63, and IgG ELISA assay were also positive (OD ratio from 3.92 to 8.36) for all six donors who had IgM reactive plasma samples (Table 2).

All donors but one had high IgG titers $(\geq 1: 320)$ (Figure 1), meeting the criteria $(\geq 1: 160)$ sponsored by the National Health Commission. However, donor D had a low IgG titer (1:40) (Figure 1), therefore this donor was not considered as an eligible donor. This donor, a 42-yearold man had the longest duration (46 days) from symptom onset to plasma collection and he had the longest duration (19 days) of hospital stay. Also, this donor had the lowest CD19+ B-cell count as well as percentage in the lymphocyte subsets analysis (Table 3).

\section{Clinical utility of CP in a critically ill patient}

The recipient for $\mathrm{CP}$ was a 64-year-old female. The patient was admitted to the hospital because of fever, fatigue, nausea and vomiting for 3 days, and was then confirmed of COVID-19. The underlying commodities included hypertension and diabetes. There was a fast progression of the clinical condition. On day 4 of hospitalization, the patient was transferred to Intensive Care Unit (ICU) and 1 week later received invasive mechanical ventilation. SARS-CoV-2 was undetectable from throat swab sample by nucleic acid test at the time of intubation. On day 17 of hospitalization, while the patient was still receiving invasive mechanical ventilation with a $\mathrm{PaO} 2 / \mathrm{FiO} 2$ of $166 \mathrm{mmHg}$, she was given $200 \mathrm{~mL} \mathrm{CP}$ from donor $\mathrm{B}$. At the time of plasma transfusion, the lymphocyte count was $0.44 \times 10^{9} / \mathrm{L}$. 
Table 1. Baseline blood examinations of the six donors when they were admitted to the hospital due to COVID-19.

\begin{tabular}{|c|c|c|c|c|c|c|c|c|c|c|c|c|c|}
\hline $\begin{array}{l}\text { Donor } \\
\text { No. }\end{array}$ & $\begin{array}{l}\text { Age, } \\
\text { y/sex }\end{array}$ & $\begin{array}{r}\text { WBC, } \\
\times 10^{9} / \mathrm{L} \\
\end{array}$ & $\begin{array}{l}\text { Lymphocyte } \\
\text { counts, } \times 10^{9} / \mathrm{L}\end{array}$ & $\begin{array}{l}\text { ALT, } \\
\text { IU/L }\end{array}$ & $\begin{array}{c}\text { Creatinine, } \\
\mu \mathrm{mol} / \mathrm{L}\end{array}$ & $\begin{array}{l}\text { CK, } \\
\mathbf{U} / \mathbf{L}\end{array}$ & $\begin{array}{l}\text { LDH, } \\
\text { IU/L }\end{array}$ & $\begin{array}{c}\text { Troponin I, } \\
\text { ng/mL }\end{array}$ & $\begin{array}{c}\text { D-dimer, } \\
\mu \mathrm{g} / \mathrm{L}\end{array}$ & PT, s & $\begin{array}{c}\text { Procalcitonin, } \\
\text { ng/mL }\end{array}$ & IL-6 & $\begin{array}{l}\text { CRP, } \\
\mathrm{mg} / \mathrm{L}\end{array}$ \\
\hline A & $30 / \mathrm{M}$ & 5.52 & 1.67 & 22.7 & 84 & 140 & 261 & 0.05 & 0.18 & 12 & 0.024 & 0.014 & $<10.00$ \\
\hline $\mathrm{C}$ & $45 / \mathrm{F}$ & 3.42 & 1.41 & 28.1 & 43 & 34 & 141 & 0.05 & 0.53 & 11.9 & 0.013 & 0.006 & 16.09 \\
\hline D & $42 / \mathrm{M}$ & 5.65 & 0.71 & 12.5 & 64.5 & 39 & 223 & 0.009 & 0.19 & 13.0 & 0.076 & 0.084 & 21 \\
\hline
\end{tabular}

WBC, white blood cell counts; ALT, alanine aminotransferase; CK, creatine kinase; LDH, lactate dehydrogenase; PT, prothrombin time; IL-6, interleukin 6; CRP, C-reactive protein; NA, not available.

Table 2. Antibody levels of six donors recovered from COVID-19.

\begin{tabular}{lccccc}
\hline $\begin{array}{l}\text { Donor } \\
\text { No. }\end{array}$ & $\begin{array}{c}\text { Blood } \\
\text { group }\end{array}$ & $\begin{array}{c}\text { Days from symptom } \\
\text { onset to plasma } \\
\text { collecting }\end{array}$ & $\begin{array}{c}\text { Days from } \\
\text { discharge to plasma } \\
\text { collecting }\end{array}$ & $\begin{array}{c}\text { Anti-SARS-CoV-2 } \\
\text { IgM levels (OD ratio) }\end{array}$ & $\begin{array}{c}\text { Anti-SARS-CoV-2 } \\
\text { IgG levels (OD } \\
\text { ratio) }\end{array}$ \\
\hline A & A & 29 & 13 & 1.47 & 7.58 \\
B & O & 36 & 17 & 1.22 & 6.59 \\
C & B & 37 & 23 & 1.55 & 7.84 \\
D & A & 46 & 27 & 2.01 & 3.92 \\
E & O & 40 & 22 & 1.95 & 7.52 \\
F & A & 39 & 27 & 5.63 & 8.36 \\
\hline
\end{tabular}

${ }^{\text {a }}$ Negative controls and positive controls were included in every run.

${ }^{\mathrm{b}}$ Serial tests were performed (Figure 1).

\section{IgG antibody levels at different titers}

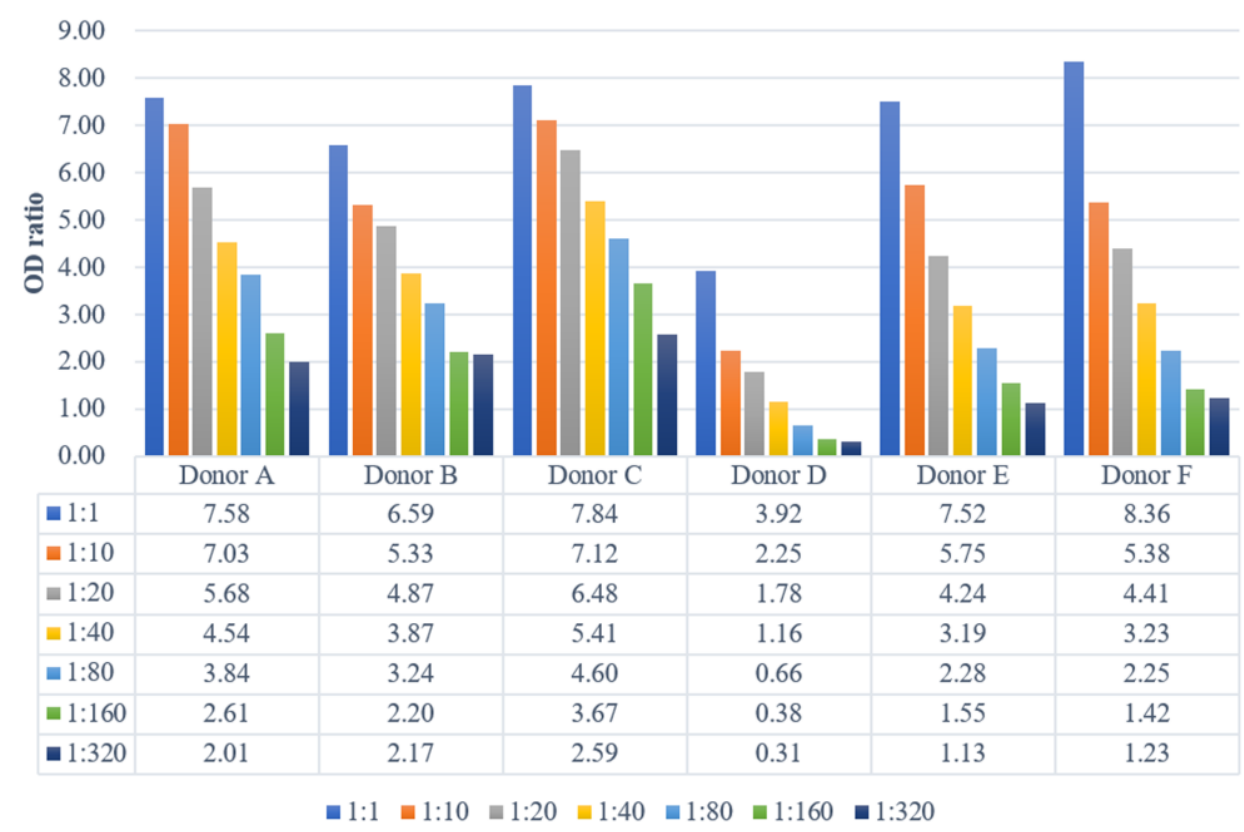

Figure 1. Specific immunoglobulin IgG were titrated by semiquantitative ELISA. Plasma IgG antibody titers ranged from $1: 40$ to $>320$. 
Table 3. Lymphocyte subsets counts of the six donors at the time of blood donation.

\begin{tabular}{|c|c|c|c|c|c|c|c|c|c|c|c|c|}
\hline $\begin{array}{l}\text { Donor } \\
\text { No. }\end{array}$ & $\begin{array}{c}\text { Lymphocyte } \\
\text { counts } \\
\text { (cells/ul) }\end{array}$ & $\begin{array}{c}\text { CD3+ } \\
(\%)\end{array}$ & $\begin{array}{c}\text { CD3+ } \\
\text { (cells/ul) }\end{array}$ & $\begin{array}{c}\text { CD3+ } \\
\text { CD4+(\%) }\end{array}$ & $\begin{array}{c}\text { CD3+CD4+ } \\
\text { (cells/ul) }\end{array}$ & $\begin{array}{c}\text { CD3+ } \\
\text { CD8+(\%) }\end{array}$ & $\begin{array}{c}\text { CD3+CD8+ } \\
\text { (cells/ul) }\end{array}$ & $\begin{array}{c}\text { CD4/CD8 } \\
\text { ratio }\end{array}$ & $\begin{array}{l}\text { CD16+CD56+ } \\
\text { NK cells }(\%)\end{array}$ & $\begin{array}{l}\text { CD16+CD56+N } \\
\text { K cells (cells/ul) }\end{array}$ & $\begin{array}{c}\mathrm{CD19+} \\
(\%)\end{array}$ & $\begin{array}{c}\text { CD19 } \\
\text { (cells/ul) }\end{array}$ \\
\hline A & 2619 & 63.23 & 1656 & 20 & 512 & 30 & 792 & 0.65 & 20.43 & 535 & 13.21 & 346 \\
\hline B & 1970 & 67.36 & 1327 & 30 & 585 & 33 & 643 & 0.91 & 19.39 & 382 & 8.07 & 159 \\
\hline $\mathrm{C}$ & 1690 & 67.81 & 1146 & 28 & 465 & 30 & 503 & 0.92 & 20.41 & 345 & 9.7 & 164 \\
\hline D & 1796 & 70.99 & 1275 & 36 & 653 & 30 & 542 & 1.2 & 21.55 & 387 & 5.57 & 100 \\
\hline E & 1841 & 57.47 & 1058 & 34 & 625 & 17 & 318 & 1.97 & 17.82 & 328 & 20.64 & 380 \\
\hline F & 1645 & 80.3 & 1321 & 52 & 850 & 25 & 416 & 2.04 & 9.3 & 153 & 9.18 & 151 \\
\hline
\end{tabular}

Other blood examinations, including renal and liver function, prothrombin time, creatine kinase, lactate dehydrogenase and myocardial enzymes, did not significantly changed, although the D-dimer was increased $(2.31 \mathrm{mg} / \mathrm{L})$. There was no transfusion related adverse event. Lymphocyte count remained below $0.5 \times 10^{9} / \mathrm{L}$ for 1 week. The patient did not require mechanical ventilation 11 days after plasma transfusion, and was then transferred to a general ward.

\section{DISCUSSION}

We reported the serological findings of SARS-CoV-2 infection in a $\mathrm{CP}$ donor population. Our preliminary findings suggest that recently recovered COVID-19 patients may be suitable potential donors, provided they meet other blood donation criteria.

Although our experience is limited in a few cases, a possibility could be suggested that, different from other viruses like MERS-CoV infection [11], antibody to SARS-CoV-2 in serum or plasma was frequently reactive by ELISA. All of the six donors showed positive IgM results, indicating that a negative result for IgM, a serologic marker which usually represents a recent or current infection [12-14], may not be suitable to be taken as a mandatory requirement for CP donor selection of limited availability of eligible potential donors in a COVID-19 outbreak. Of the six donors, only one donor had IgG titers of 1:40, which did not meet the criteria 1:160 recommended by the National Health Commission. Of note, compared with other donors, he experienced a severe disease, and had the longest duration from symptom onset to plasma collection, we suspected whether this phenomenon was related to his low CD19+ B-cell count or he had experienced a viral reactivation-an observation that requires further investigation.

However, due to limitations imposed by sample size, reactivity of ELISA tests may also be affected by the timing of plasma collection, severity of illness or corticosteroids administration. In addition, although this life-threatening disease appear to be under control following nationwide efforts and implementation of quarantine policy in China, but it is still developing in the other parts of the world. As yet no reference materials of anti-SARS-CoV-2 antibodies has been made available to evaluate the performance of the kits. Our study highlights the need for prospective serology studies and good laboratory quality assurance to better understand the humoral response to SARS-CoV-2 infection.

The weakness of the study should be noted that the clinical relevance of antibody titers in protecting against subsequent SARS-CoV-2 infection is uncertain. Compared to ELISAs, neutralization assays require virus culture, are much more labor-intensive, and need to be conducted in laboratories with higher biosafety levels $[15,16]$. We are currently conducting neutralization studies to further investigate whether ELISA results were correlated with neutralization results so far as to substitute for the neutralization test in resource-limited situations.

Although a favorable outcome was achieved in one patient after $\mathrm{CP}$ transfusion, the efficacy of $\mathrm{CP}$ remains inconclusive due to the very small sample size and other concomitant treatments, which might confound the result.

In summary, we presented serologic findings from six CP donors recovered from COVID-19 and one case treated with CP. This report may help facilitate understanding of the SARS-CoV-2 infection and establish donor screening protocol for $\mathrm{CP}$ infusion therapeutics in the COVID-19 outbreak.

\section{MATERIALS AND METHODS}

\section{Study design}

Under the first and second edition of $\mathrm{CP}$ infusion therapeutics guidelines approved by the National 
Health Commission, we developed a protocol for donor screening, plasma collection and specimen analysis to screen potential donors and collect hightiter plasma. Donor screening, specimen collecting and convalescent plasma collecting were conducted at the Second Hospital of Nanjing, a designated medical institution for COVID-19. The antibody testing was conducted in Nanjing Red Cross Blood Center, and its Department of Laboratory Medicine is accredited by China National Accreditation Service for Conformity Assessment. This study was approved by the ethics committee of the Second Hospital of Nanjing (reference number: 2020-LS-ky003). Written informed consent was obtained from all the donors and the recipient.

\section{Donor population}

We screened potential convalescent plasma donors from patients who were confirmed SARS-CoV-2 infection by PCR and had recovered at least four weeks from symptom onset. A total of eight volunteers were recruited as potential plasma donors for assessment. Two were excluded because of elevated alanine transaminase for one case and unexpected hemoglobin levels for the other case. The remaining six provided written, informed consent to become qualified donors.

\section{Collection of specimens for antibody levels}

Convalescent plasma was collected by apheresis from COVID-19 recovered donors, and specimen for antibody testing were collected from an integrated bypass collection reserved sample bag. Plasma for determination of anti-SARS-CoV-2 IgG antibody levels was collected in EDTA tubes and serum for anti-SARSCoV-2 IgM antibody levels was collected in tubes with coagulation accelerators. Samples were delivered to Nanjing Red Cross Blood Center immediately after collecting, followed by sample centrifuging and antibody testing.

\section{Serology tests}

Two solid-phase microplate ELISAs were employed, based on the nucleocapsid (N) protein of SARS-CoV-2 (Livzon, Diagnostics Inc., Zhuhai, China).

The first kit was a capture enzyme-linked immunosorbent assay for IgM antibody using horseradish peroxidase (HRP)-labeled SARS-CoV-2 antigens. To reveal IgM, serum samples were diluted 1:100 in dilution buffer and allowed to incubate for $60 \mathrm{~min}$ with plates coated by anti-human IgM $\mu$ chain. Plates were washed and HRPlabeled antigens were added. After 30 min incubation, unbound components were washed away, following adding of TMB substrate with its buffer. For a further 15 min incubation, stop buffer was added and absorbance values were measured at $450 \mathrm{~nm}$ and $630 \mathrm{~nm}$ dual-wavelength using a microplate reader.

The second kit was an indirect enzyme-linked immunosorbent assay designed for IgG antibody. After a formulated 1:20 predilution according to the ELISA manufacturer's instructions, plasma specimens were serially titrated 1:1, 1:10, 1:20, 1:40, 1:80, 1:160 and 1:320 in microplates by plasma from unexposed donors and added to plates coated with SARS-CoV-2 antigens. Following $60 \mathrm{~min}$ incubation at $37^{\circ} \mathrm{C}$, plates were washed and incubated with horseradish peroxidaselabeled anti-human IgG secondary antibody. Again, plates were washed following $30 \mathrm{~min}$ incubation at $37^{\circ} \mathrm{C}$ and TMB substrate was added with its buffer. 15 min later, stop buffer was added and absorbance values were measured at $450 \mathrm{~nm}$ and $630 \mathrm{~nm}$ dualwavelength using a microplate reader.

Results were reported as the optical density (OD) ratio, which was calculated as the OD value of the donor's sample divided by the cutoff OD value. We used cutoff values recommended by the ELISA kit manufacturer: a ratio of $<1$ was considered negative, and $\geq 1$ was considered positive.

\section{Statistical methods}

All data from measurements were displayed as tables and a histogram.

\section{Abbreviations}

CP: convalescent plasma; COVID-19: coronavirus disease 2019; WBC: white blood cell counts; ALT: alanine aminotransferase; CK: creatine kinase; $\mathrm{LDH}$ : lactate dehydrogenase; PT: prothrombin time; IL-6: interleukin 6; CRP: C-reactive protein; NA: not available; OD: optical density; ICU: Intensive Care Unit.

\section{AUTHOR CONTRIBUTIONS}

L.B.Z. and R.R.P. performed the experiments and wrote the paper. X.X. participated in the design of the study and contributed with comments during the writing. J.J.B. and S.Y. performed the experiments and conducted data analysis. Y.D.D. reviewed the manuscript. Y.S.Z participated in the clinical utility of CP. Q.F. and Z.L.H. conceived the study and collected the data. Y.X.Y. participated in the design of the study. All authors read and approved the final manuscript. 


\section{ACKNOWLEDGMENTS}

We gratefully acknowledge the intense individual effort and support from many sources to make this study possible and the contributions of plasma donors.

\section{CONFLICTS OF INTEREST}

The authors declare that they have no conflicts of interests.

\section{FUNDING}

This study was supported by Medical Science and technology development Foundation, Nanjing Department of Health (ZKX18050). Dr. Xiang Xue is supported by the National Institutes of Health (K01DK114390) and a Research Scholar Grant from the American Cancer Society (RSG-18-050-01-NEC).

\section{REFERENCES}

1. Velavan TP, Meyer CG. The COVID-19 epidemic. Trop Med Int Health. 2020; 25:278-80.

https://doi.org/10.1111/tmi.13383

PMID:32052514

2. Wu Z, McGoogan JM. Characteristics of and Important Lessons From the Coronavirus Disease 2019 (COVID19) Outbreak in China: Summary of a Report of 72314 Cases From the Chinese Center for Disease Control and Prevention. JAMA. 2020; 323:1239.

https://doi.org/10.1001/jama.2020.2648

PMID:32091533

3. Chen L, Xiong J, Bao L, Shi Y. Convalescent plasma as a potential therapy for COVID-19. Lancet Infect Dis. 2020; 20:398-400.

https://doi.org/10.1016/S1473-3099(20)30141-9 PMID: 32113510

4. Zhang L, Liu Y. Potential interventions for novel coronavirus in China: A systematic review. J Med Virol. 2020; 92:479-90.

https://doi.org/10.1002/jmv.25707

PMID: $\underline{32052466}$

5. Garraud O. Use of convalescent plasma in Ebola virus infection. Transfus Apher Sci. 2017; 56:31-34.

https://doi.org/10.1016/j.transci.2016.12.014 PMID:28094110

6. Wu XX, Gao HN, Wu HB, Peng XM, Ou HL, Li LJ. Successful treatment of avian-origin influenza A (H7N9) infection using convalescent plasma. Int J Infect Dis. 2015; 41:3-5. https://doi.org/10.1016/j.ijid.2015.10.009 PMID:26482389
7. Mair-Jenkins J, Saavedra-Campos M, Baillie JK, Cleary P, Khaw FM, Lim WS, Makki S, Rooney KD, NguyenVan-Tam JS, Beck CR, and Convalescent Plasma Study Group. The effectiveness of convalescent plasma and hyperimmune immunoglobulin for the treatment of severe acute respiratory infections of viral etiology: a systematic review and exploratory meta-analysis. J Infect Dis. 2015; 211:80-90.

https://doi.org/10.1093/infdis/jiu396

PMID:25030060

8. Choi S, Kim MC, Kwon JS, Kim JY, Lee KH, Kim SH. Case Report: Use of Plasma Exchange Followed by Convalescent Plasma Therapy in a Critically III Patient with Severe Fever and Thrombocytopenia SyndromeAssociated Encephalopathy: Cytokine/Chemokine Concentrations, Viral Loads, and Antibody Responses. Am J Trop Med Hyg. 2018; 99:1466-68. https://doi.org/10.4269/aitmh.17-0766 PMID:30277197

9. Ko JH, Seok H, Cho SY, Ha YE, Baek JY, Kim SH, Kim YJ, Park JK, Chung CR, Kang ES, Cho D, Müller MA, Drosten $C$, et al. Challenges of convalescent plasma infusion therapy in Middle East respiratory coronavirus infection: a single centre experience. Antivir Ther. 2018; 23:617-22. https://doi.org/10.3851/IMP3243 PMID:29923831

10. Tedder RS, Samuel D, Dicks S, Scott JT, ljaz S, Smith CC, Adaken C, Cole C, Baker S, Edwards T, Kamara P, Kargbo O, Niazi S, et al, and Ebola_CP Consortium Investigators. Detection, characterization, and enrollment of donors of Ebola convalescent plasma in Sierra Leone. Transfusion. 2018; 58:1289-98. https://doi.org/10.1111/trf.14580 PMID:29572862

11. Arabi YM, Hajeer AH, Luke $\mathrm{T}$, Raviprakash $\mathrm{K}$, Balkhy $\mathrm{H}$, Johani S, Al-Dawood A, Al-Qahtani S, Al-Omari A, AlHameed F, Hayden FG, Fowler R, Bouchama A, et al. Feasibility of Using Convalescent Plasma Immunotherapy for MERS-CoV Infection, Saudi Arabia. Emerg Infect Dis. 2016; 22:1554-61.

https://doi.org/10.3201/eid2209.151164 PMID:27532807

12. Aljumaili ZK, Alsamarai AM, Najem WS. Cytomegalovirus seroprevalence in women with bad obstetric history in Kirkuk, Iraq. J Infect Public Health. 2014; 7:277-88.

https://doi.org/10.1016/i.jiph.2013.08.006 PMID:24629348

13. Samanta D, Willis E. Focal seizure associated with human parvovirus B19 infection in a nonencephalopathic child. World J Pediatr. 2016; 12:118-20.

https://doi.org/10.1007/s12519-015-0060-0 PMID:26684306 
14. Singh L, Mishra S, Prasanna S, Cariappa MP. Seroprevalence of TORCH infections in antenatal and HIV positive patient populations. Med J Armed Forces India. 2015; 71:135-38.

https://doi.org/10.1016/j.mjafi.2014.12.009

PMID:25859075

15. Brown JF, Dye JM, Tozay S, Jeh-Mulbah G, Wohl DA, Fischer WA 2nd, Cunningham CK, Rowe K, Zacharias $\mathrm{P}$, van Hasselt J, Norwood DA, Thielman NM, Zak SE, Hoover DL. Anti-Ebola Virus Antibody Levels in Convalescent Plasma and Viral Load After Plasma
Infusion in Patients With Ebola Virus Disease. J Infect Dis. 2018; 218:555-62.

https://doi.org/10.1093/infdis/jiy199

PMID:29659889

16. Chen J, Zhu H, Horby PW, Wang $Q$, Zhou J, Jiang $H$, Liu L, Zhang T, Zhang Y, Chen X, Deng X, Nikolay B, Wang $W$, et al. Specificity, kinetics and longevity of antibody responses to avian influenza $A(H 7 N 9)$ virus infection in humans. J Infect. 2020; 80:310-19.

https://doi.org/10.1016/j.jinf.2019.11.024

PMID:31954742 